\title{
Determinants of Career Aspiration: An Empirical Study on Masters of Business Administration Students of Selected Two National Universities in \\ Sri Lanka
}

\author{
Fernando, RTW and Jayasekara, $P$
}

\begin{abstract}
Area of the Study

Career aspiration is one of the constructs of Career Development. Therefore this study is to identify the determinants of career aspiration and its relationship with career aspiration of Masters of Business administration (MBA) students in selected two national universities in Sri Lanka.
\end{abstract}

\section{Problem of the Study}

Empirical and theoretical gap to identify the determinants of career aspiration and their relationship with career aspiration of Masters of Business Administration (MBA) students in selected two national universities in Sri Lanka.

\section{Method of the Study}

The data was collected from 153 respondents (MBA students) in the University of Sri Jayewardenepura and University of Colombo by administrating a structured questionnaire which consisted of 22 questions/statements with five point Likert scale. The data analysis included the correlation and regression analysis conducted using SPSS 16.0 (Version).

\section{Findings of the Study}

It was found that there is a strong positive relationship between intrinsic factors and career aspiration. There was a moderate relationship between job related factors and career aspiration while there was a negative relationship between familial factors and career aspiration.

\section{Conclusion of the Study}

Since there is a strong relationship between intrinsic factors and career aspiration, when developing new career development programmes, management should pay their attention to develop individual factors.

Keywords: Career Aspiration, Intrinsic Factors, Extrinsic Factors, Job Related Factors, Familial Factors

\section{Introduction}

Everyone in this world wants to be stable. In this regard one must choose a professional career which should be continued throughout the life. In that instance individuals engage in several occupational positions over many years which is called as a career (Dessler cited in Eðvarðsson and Óskarsson, 2011). Career is not just a job, but it is about implementation ideas of planned and structured advancement that leads to career development (Ramly, Ismail \& Uli, 2009). 
Career Development is one of the three areas of practices for Human Resource Development (McLagan, 1989). Career development is a lifelong process through which we come to understand our place in both the world of work and in society. The most popular goal in career development activities is to encourage the exploration of many alternatives in the profession (Ramly, Ismail \& Uli, 2009). The importance of career development is likely to differ according to individuals. But for many people, a successful career is a significant contributor to personal happiness and financial security. One of the constructs of career development is career aspiration. A very good knowledge of human aspiration is essential to understand career development (Gottfredson, Holland and Gottfredson, 1975). Inspired career is determined by several factors called as intrinsic factors, extrinsic factors, job related factors and familial factors. This study is aimed to discuss the career determinant of MBA students in Sri Lanka.

\section{Problem Background and Problem of the Study}

Career aspiration is not a very famous topic in most of the countries. Majority of career aspiration researches have been conducted considering adolescence. Career aspiration plays a significant role in selecting a person's career and his or her career development (Ramly, Ismail and Uli, 2009). In such scenario, factors that influence career aspiration need to be identified in order to better understand career aspiration (Ramly, Ismail and Uli, 2009). In the Sri Lankan context the available empirical findings are not enough to cover the concept of career aspiration. Thus, there is a need to fulfill the knowledge gap in this field. This research therefore, tries to find the determinants of career aspiration and their relationship with career aspiration of MBA students in two national universities in Sri Lanka. Therefore, the research problem addressed under this study is: What are the determinants of career aspiration and their relationship with career aspiration of Masters of Business Administration (MBA) students in selected two national universities in Sri Lanka.

\section{Research Framework}

Intrinsic Factors: Intrinsic factors (individual factors) are the main factors that shape an individual's career aspiration (Rahaman and Goswami, 2013). According to Gallhena and Rathnayake (2011) skills and abilities and educational background were the main factors that influence a career decision making. Further there are empirical evidences that skills and abilities (Sewell and Hauser, 1980; Furlong and Biggart, 1999) and educational background (Domenico and Jones, 2006; Karami, Ismail and Sali, 2011; Cha and Chung, 2009; Tremblay, Wils and Proulx, 1998) influence an individual's career aspiration. Other than the above, Ismail and Ramly (2011); Elizabeth (2012); Aremu and Lawal (2009); Ramly, ismail and Sali (2009) research findings suggest that self efficacy is also another individual factor that influences the career aspiration. Thus the first Hypothesis is developed as follows;

$\mathrm{H}_{1}$ : There is a positive relationship between intrinsic factors and career aspiration of $M B A$ students.

Extrinsic Factors: Galhena and Rthnayake (2011) in their research have identified influence from friends is a significant inspiring factor. Further the social support from teachers is 
another factor that affects career aspiration (Mutekwe, Modiba and Maphosa, 2011; Brown and Barbosa cited in Domenico and Jones, 2006; Shumba and Naong, 2012). Influence of peer is also another contributing factor of career aspiration (Mutekwe, Modiba and Maphosa, 2011; Wilson et al. cited in Mutekwe, Modiba and Maphosa, 2011; Fisher and Griggs cited in Mutekwe, Modiba and Maphosa, 2011). As a result, researcher proposes the following as the second hypothesis.

$\mathrm{H}_{2}$ : There is a positive relationship between extrinsic factors and career aspiration of $M B A$ students.

Job Related Factors: Financial rewards, non financial rewards are the main factors that come under job related factors (Galhena and Rthnayake, 2011). As cited in Tremblay, Wils and Proulx (1998) Aryee has also stated that there is a link between career aspiration and reward system. Therefore the next hypothesis is,

$\mathrm{H}_{3}$ : There is a positive relationship between job related factors and career aspiration of MBA students.

Familial Factors: Galhena and Rathnayake (2011) have identified that push from parents and other family members supports as the main contributing determinant of career aspiration. Domenico and Jones (2006), Shumba and Naong (2012), Mutekwe, Modiba and Maphosa (2011) and Mau and Biko (2000) have found that parental push is a significant determinant in career aspiration. Therefore as the fourth hypothesis researcher suggests,

$\mathrm{H}_{4}$ : There is a positive relationship between familial factors and career aspiration of $M B A$ students.

Gender: According to the findings of Obura and Ajowi (2012), Chow (1995), Correll (2004) and O'Neill and O'Reilly (2004) it could be identified that there is a moderating impact of gender on career aspiration. Hence the final hypothesis could be suggest as, $\mathrm{H}_{5}$ : There is a moderating impact of gender on career aspiration of MBA students.

Figure 1: The factors affecting for career aspiration

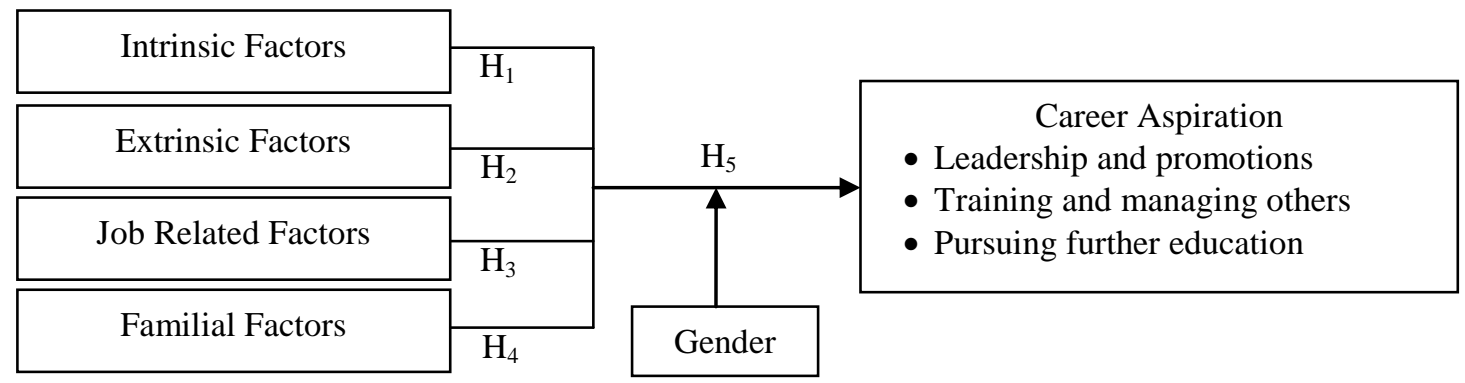

\section{Method}

\section{Study design}

The objective is to identify the determinants of career aspiration and their relationship with career aspiration. Therefore the type of investigation of this study was correlation. Further the impact of each independent variable on dependent variable is measured by a regression analysis. None of the variables were controlled or manipulated. As the study was conducted 
in the natural environment where events normally occur, it is a non - contrived setting: no any artificial or contrived setting was created for the study.

\section{Measures}

The sample used in this questionnaire was 153. The data is gathered by a structured questionnaire. Part one of the questionnaire consisted of identification information. Part two of the questionnaire measures the determinants of career aspiration of MBA students. The factors identified by Galhena and Rathnayake (2011) were used in developing the questionnaire. The questionnaire for measuring the aspiration which is the third part was a standard questionnaire which was originally developed by Gray and O'Brien in 2007. It contained 8 statements which measures three dimensions of career aspiration. The questions were measured by their responses to the questionnaire with five point Likert scale. This research model consists of six variables. According to conceptual framework intrinsic factors, extrinsic factors, job related factors and familial factors were the independent variables while career aspiration was the dependent variable. In this research gender was considered as a moderating factor.

\section{Reliability and Validity of the Instruments}

The content reliability was examined with Cronbach's Alpha (Kottawatta 2014) and reliability of each variable was found to be greater than 0.700 . The results of Cronbach's alpha test suggest that the internal reliability of each instrument (Kottawatta 2014). The content validity of the instruments was ensured by the conceptualization of the variables on literature (Kottawatta 2014) and the content validity of the variables of the study was ensured by the fact that the correlation support the hypotheses formulated linking the relationship between the independent variables and the dependent variable (Kottawatta 2014).

\section{Techniques of Data Analysis}

Collected data are analyzed using the computer based statistical data analysis package, SPSS version 16.0 (Version) for validity, reliability and hypotheses testing.

\section{Results}

The questionnaire distributed among MBA students of University of Sri Jayewardenepura and University of Colombo. Majority of respondents were male which is $95(62.1 \%)$ while (58) $37.9 \%$ were female. When it comes to the age category $55.6 \%$ of the respondents were represented in the age category of $25-30.24 .2 \%$ of the respondents were in the age category of $31-35$ while $11.1 \%$ of the respondents were in the age category of 36-40. Respondents who are in the age category of over 46 represented $2 \%$ which was the least percentage. 
Table 1 : Correlation Analysis

\begin{tabular}{|c|c|c|c|c|c|}
\hline & & $\begin{array}{r}\text { Intrinsic } \\
\text { Factors }\end{array}$ & $\begin{array}{r}\text { Extrinsic } \\
\text { Factors }\end{array}$ & $\begin{array}{r}\text { Job Related } \\
\text { Factors }\end{array}$ & $\begin{array}{r}\text { Familial } \\
\text { Factors }\end{array}$ \\
\hline \multirow{3}{*}{$\begin{array}{l}\text { Intrinsic } \\
\text { Factors }\end{array}$} & Pearson Correlation & 1 & & & \\
\hline & Sig. (2-tailed) & & & & \\
\hline & $\mathrm{N}$ & 153 & & & \\
\hline \multirow{3}{*}{ Extrinsic } & Pearson Correlation & $.300^{* *}$ & 1 & & \\
\hline & Sig. (2-tailed) & .000 & & & \\
\hline & $\mathrm{N}$ & 153 & 153 & & \\
\hline \multirow{3}{*}{ Job Related } & Pearson Correlation & $.763^{* *}$ & $.334^{* *}$ & 1 & \\
\hline & Sig. (2-tailed) & .000 & .000 & & \\
\hline & $\mathrm{N}$ & 153 & 153 & 153 & \\
\hline \multirow{3}{*}{$\begin{array}{l}\text { Familial } \\
\text { Factors }\end{array}$} & Pearson Correlation & .000 & .141 & -.058 & 1 \\
\hline & Sig. (2-tailed) & .998 & .083 & .473 & \\
\hline & $\mathrm{N}$ & 153 & 153 & 153 & 153 \\
\hline \multirow{3}{*}{$\begin{array}{l}\text { Career } \\
\text { Aspiration }\end{array}$} & Pearson Correlation & $.650^{* *}$ & $.182^{*}$ & $421^{* *}$ & $-.204^{*}$ \\
\hline & Sig. (2-tailed) & .000 & .025 & .000 & .011 \\
\hline & $\mathrm{N}$ & 153 & 153 & 153 & 153 \\
\hline
\end{tabular}

**. Correlation is significant at the 0.01 level (2-tailed).

*. Correlation is significant at the 0.05 level (2-tailed).

As shown in Table 1 Pearson Correlation between intrinsic factors and career aspiration is, $\mathrm{r}$ $=.650$ which is positive and significance. And $\mathrm{p}$ value is 0.000 which is lower than 0.01 . The relationship can be considered as positive which is significant relationship at $99 \%$ confidence level (2-tailed). Pearson Correlation between extrinsic factors and career aspiration was $\mathrm{r}=$ .182 which is a positive and significance at $95 \%$ confidential level. Because $\mathrm{p}$ value is 0.025 which is lower than 0.05 . Thus it can be considered that there is a positive relationship between extrinsic factors and career aspiration. As illustrated in Table 1 Pearson Correlation between job related factors and career aspiration was $\mathrm{r}=.421$ which is positive and significant and $\mathrm{p}$ value is 0.000 which is lower than 0.01 . The found relationship is statistically significant since correlation is significant at $99 \%$ confidence level (2-tailed). Pearson Correlation between familial factors and career aspiration was $r=-.204$ which is negative and significant $\mathrm{p}$ value is 0.025 which is lower than 0.05 . The found negative relationship is statistically significant since correlation is significant at $95 \%$ confidence level (2-tailed).

To measure the impact of intrinsic factors, extrinsic factors, job related factors and familial factors on career aspiration, a regression analysis was done. The results are summarized in Table 2.

Table 2 : Regression Analysis Results

\begin{tabular}{|l|r|r|r|r|}
\hline & Intrinsic Factors & Extrinsic Factors & $\begin{array}{r}\text { Job Related } \\
\text { Factors }\end{array}$ & Familial Factors \\
\hline B Constant & 1.945 & 3.555 & 2.911 & 4.404 \\
\hline$\beta$ Valuie & .650 & .182 & .421 & -.204 \\
\hline R Square & .422 & .033 & .177 & .042 \\
\hline F & 110.371 & 5.144 & 32.510 & 6.581 \\
\hline Significance & .000 & .025 & .000 & .011 \\
\hline
\end{tabular}


As per Table 2 regression equation of intrinsic factors of MBA students is:

$$
\text { Career Aspiration }=1.945+.650 \mathrm{x}+\mathrm{e}
$$

The $\beta$ value of the equation is the gradient of the regression, is .650 which is significant $(\mathrm{p}=$ .000 ). Further $\beta$ shows the significance of the independent variables as a predictor of dependent variable. As indicated by $\mathrm{R}$ squared, $42.2 \%$ of the variance of career aspiration is explained by intrinsic factors of this study setting. Thus intrinsic factors can be considered as a significant predictor of career aspiration.

According to Table 2, regression equation of extrinsic factors of MBA students is:

$$
\text { Career Aspiration }=3.555+.182 \mathrm{x}+\mathrm{e}
$$

The $\beta$ value of the equation is the gradient of the regression, is .182 which is significant ( $\mathrm{p}=$ $.025)$. As indicated by R squared, only $3.3 \%$ of the variance of career aspiration is explained by extrinsic factors.

The equation for the job related factors is:

$$
\text { Career Aspiration }=2.911+.421 \mathrm{x}+\mathrm{e}
$$

As indicated by Table 3 the $\beta$ value of the equation is the gradient of the regression, is .421 which is significant $(\mathrm{p}=.000)$. As indicated by $\mathrm{R}$ squared, $17.7 \%$ of the variance of career aspiration is explained by job related factors. Thus job related factors can be considered as a significant predictor of career aspiration.

The final equation in the regression analysis according to Table 2 is for familial factors. That is:

$$
\text { Career Aspiration }=4.404-.204 \mathrm{x}+\mathrm{e}
$$

The $\beta$ value of the equation is the gradient of the regression, is -.204 which is significant $(\mathrm{p}=$ .011 ). As indicated by $\mathrm{R}$ squared, $4.2 \%$ of the variance of career aspiration is explained by familial factors.

According to set objectives, there is a moderating impact on gender on career aspiration. The moderating impact is measured by a stepwise regression analysis which is summarized in Table 3. 
Table 3 : Moderating Impact of Gender

\begin{tabular}{|l|r|r|}
\hline \multirow{2}{*}{} & \multicolumn{2}{|c|}{ Dependent Variable : Career Aspiration } \\
\cline { 2 - 3 } & Model $1(\beta)$ & Model $2(\beta)$ \\
\hline All factors of Career aspiration & $.342^{*}$ & $.583^{*}$ \\
\hline Gender & -.158 & .234 \\
\hline $\begin{array}{l}\text { All factors of Career aspiration } \mathrm{x} \\
\text { Gender }\end{array}$ & & -.439 \\
\hline $\mathrm{R}$ & & .405 \\
\hline $\mathrm{R}^{2}$ & .396 & .164 \\
\hline $\mathrm{R}$ square change & .157 & .007 \\
\hline F Value & .157 & 9.676 \\
\hline Significance & 13.865 & .515 \\
\hline
\end{tabular}

The $\beta$ value of the model one (excluding moderating factor) was .342 while $\beta$ of Model two was .583 . The $\beta$ value of gender was -.158 in model one while $\beta$ of model two was .234 . The $\mathrm{R}^{2}$ of the model one was .157. It indicates that the $15.7 \%$ of the variance of career aspiration is explained by the all the factors affecting career aspiration. But in contrast when it comes to the analysis with the moderating factor, the $\mathrm{R}^{2}$ was amounted .164 . Only $16.4 \%$ of career aspiration is explained by all the factors affecting career aspiration along with the moderating factor. The $\mathrm{F}$ value has decreased from 13.865 to 9.676 after considering the moderation impact of gender. The change of $\mathrm{R}^{2}$ was $.007(0.7 \%)$. However, the significant level is $\mathrm{p}=0.515$ and it is not statistically support to accept the hypothesis 5 of the study. Thereby gender differences do not moderate the relationship between the identified constructs of the study.

\section{Discussion and Conclusion}

According to the regression analysis, it was found that there is a significant positive relationship which is $r=.650$ between intrinsic factors and career aspiration. The p value was .000 which was significant at $99 \%$ confidence level. Therefore according to the above results the set hypothesis of "There is a positive relationship between intrinsic factors and career aspiration of MBA students" is accepted. This finding is supported by the research carried by Gallhena and Rathnayake (2011). In his study it was found that skills and abilities and educational background which are considered as intrinsic factors are the main factors that influence a career decision making. Ismail and Ramly (2011), Aremu and Lawal (2009) and Elizabeth (2012) research findings suggest that self efficacy is also an individual factor that influences the career aspiration.

It was found that there is a positive and significant relationship between extrinsic factors and career aspiration. Correlation was $r=.182$ while $\mathrm{p}$ value was .025 which is significant at $95 \%$ confidence level. Above results are also supported by the Galhena and Rathnayake (2011) findings. Educational opportunities, success stories of friends and family (influence from others) are main inspiring factors. Similarly influences from others such as friends, teachers \& etc. make an impact on career aspiration of individuals (Mutekwe, Modiba and Maphosa, 2011). According to the results the set hypothesis of "There is a positive relationship between Extrinsic factors and career aspiration of MBA students" is accepted. 
The identified relationship in the correlation analysis between job related factors and career aspiration was positive and significant. Correlation was $r=.421$ while $\mathrm{p}$ value was .000 which is significant at $99 \%$ confidence level. The set hypothesis of "There is a positive relationship between job related factors and career aspiration of MBA students" is accepted based on above results. Hence the data support the hypothesis that there is a positive relationship between job related factors and Career aspiration of MBA students of the sample universities. The above results are in line with the findings of Gallhena and Rathnayake (2011). In the study of Gallhena and Rathnayake (2011) it was identified that financial rewards and non financial rewards are the main factors that affect the career aspiration.

According to the regression analysis, it was found that there is a significant negative relationship which is $r=-.204$ between familial factors and career aspiration. The $\mathrm{p}$ value was .025 which was significant at $5 \%$. Therefore according to the results, the set hypothesis of "There is a positive relationship between Familial factors and career aspiration of MBA students" is not accepted. The above negative relationship between familial factors and career aspiration is contrasting with the findings of previous research. Galhena and Rathnayake (2011) have identified several familial factors that affect career choice decision making. They have identified that parental push make a positive impact on career choice decision making. Further it was found that families, parents and guardians play a very important role in the occupational aspirations and career goal development of their children (Shumba and Naong, 2012). When it comes to the Sri Lankan context there was a negative relationship between familial factors and career aspiration.

According to the results of regression analysis it was found that there is no moderating impact of gender since $F$ value was not significant. The resulted p value was .515 ( $p>.05$ ) and $F$ value is 9.676 which is not significant. But in contrast, Chow's (1995) findings suggest that there is an occupational segregation between men and women in Hong Kong. Further as explained by Correll (2004) human capital theorists assume that different tastes, preferences are held by males and females when selecting a career.

However the findings support some research results. Some research findings have identified that the occupational aspirations are similar between men and women (Gary, Powell and Butterfield, 2003). Further it was identified that sex segregation among occupations has been diminished over the time. The findings of Lee and Rojewski (n.d) suggest that female adolescents report occupational aspirations that are equal or greater than to their male peers. Gary, Powell and Butterfield (2003) further suggest that the reason for the reduction of gender difference in occupational aspiration as a result of societal change. Since there is no moderation impact, this reduction of gender difference may be seen in the Sri Lankan context as well.

\section{Managerial Implications and Recommendation}

According to Rmaly, Ismail and Uli (2009) career aspiration is considered as a good catalyst of career development. Among the determinants of career aspiration, it was found that 
intrinsic factors and career aspiration had a strong positive relationship. Intrinsic factors were composed of skills and abilities, educational level and self efficacy. Therefore when developing new career development programmes, management should pay their attention to develop individuals' self efficacy such as career motivation talks and confidence building programmes and skills and abilities which will finally result in an increase of human capital in the organization.

It is recommended that further studies could be considered to compare the determinants of career aspiration for different ethnic groups and groups with different belief systems. The findings of such studies may help organizations to introduce more particular intervention plans to promote the career aspirations towards its staff with different background in terms of race, religion or culture.

\section{References}

1. Aremu, AO \& Lawal, GA 2009, 'A path model investigating the influence of some personal-psychological factors on the career aspirations of police trainees: a perspective from Oyo State, Nigeria, Police Practice and Research', An International Journal, Vol. 10, pp. 239-254.

2. Cha, M \& Chang, W 2009, 'Learning through working: A case study of Chinese college students in South Korea', Asia Pacific Journal of Education, Vol. 29, pp. 311320.

3. Chow, IH 1995, 'Career aspirations, attitudes and experiences of female managers in Hong Kong', Women in Management Review, Vol. 10, pp. 28-32.

4. Correll, SJ 2004, 'Constraints into Preferences: Gender, Status, and Emerging Career Aspirations', American Sociological Review, Vol. 69, pp. 93-113.

5. Domenico, DM \& Jones, KH 2006, 'Career Aspirations of Women in the 20th Century', Journal of Career and Technical Education, pp. 1-7.

6. Eðvarðsson, IR \& Óskarsson, GK 2011, 'The choice of Career after graduation: The case of business administration graduates from a small university', Vorráðstefna Viðskiptafraeðistofnunar Háskóla Íslands, pp. 120-128.

7. Elizabeth, M 2012, 'Factors Affecting Career Aspirations of Girls; Emerging Issues And Challlenges: A Case Of Thika West District, Kiambu County', Kenyatta University, Viewed $27^{\text {th }}$ September.

8. Furlong, A \& Biggart, A 1999, 'Framing 'choices': A longitudinal study of occupational aspirations among 13 to 16 year olds', Journal of Education and Work, Vol. 12, pp. 21-35.

9. Galhena, BL \& Rathnayake, RMDD 2011, 'Determinants of career choice decision of management undergraduates in Sri Lanka', ICBI, pp. 1-12.

10. Gary, N, Powell, D \& Butterfield, A 2003, 'Gender, gender identity, and aspirations to top management', Women in Management Review, Vol. 18, pp. 88-96.

11. Gottfredson, GD, Holland, JL \& Gottfredson, LS 1975, 'The relation of vocational aspirations and assessments to employment reality', Journal of Vocational Behavior, Vol. 7, pp. 135-148. 
12. Gray, MP \& O'Brien, KM 2007, 'Advancing the Assessment of Women's Career Choices: The Career Aspiration Scale', Journal Of Career Assessment, Vol. 15, pp. 317-337.

13. Ismail, M \& Ramly, ES 2011, 'Career aspirations of Malaysian research and development professionals in the knowledge economy', Journal of European Industrial Training, Vol. 35, pp. 606-622.

14. Karami, R, Ismail, M \& Sali, RM 2011, 'Gender identity and career aspiration to top management of Malaysian graduate students', Asia Pacific Journal of Education, Vol. 31, pp. 439-454.

15. Kottawatta, H 2014, Research guide book, Department of Human Resource Management, Colombo.

16. Lee, IH \& Rojewski, JW n.d., 'Development of Occupational Aspiration Prestige: A Piecewise Latent Growth Model of Selected Influences', pp. 1-14.

17. Mau, W \& Bikos, L 2000, 'Educational vocational aspirations of minority and female students: A longitudinal study', Journal of Counseling \& Development, Vol. 78, No. 2, pp. 186-194.

18. McLagan, PA 1989, 'Models for HRD practice', Training and Development Journal, Vol. 43, No. 9, pp. 49-59.

19. Mutekwe, E, Modiba, M \& Maphosa, C 2011, 'Factors Affecting Female Students' Career Choices and Aspirations: A Zimbabwean Example', Journal of Social Science, Vol. 29, pp. 133-141.

20. O’Neill, OA \& O’Reilly, CA 2004, 'The Impact of Sex and Gender Identity on Career Attainment, 1775, pp.1-37.

21. Obura, CA \& Ajowi, JO 2012, 'Gender and Students' Perceptions of Career Aspirations in Secondary schools', Academic Journal of Interdisciplinary Studies, Vol. 1, pp. 149-164.

22. Rahman, A \& Goswami, D 2013, 'Level Of Aspiration Of Undergraduate Students In Relation To Their Sex And Socio-Economic Status', International Journal of Humanities and Social Sciences (IJHSS), Vol. 2, No. 1, pp. 79-86.

23. Ramly, ES, Ismail, M \& Uli, J 2009, 'Antecedents of Career Aspiration of Rand D Professionals in Malaysian Public Organizations', European Journal of Scientific Research, Vol. 26, No. 1, pp. 66-79.

24. Sewell, WH \& Hauser, D 1980, 'Sex, schooling, and occupational status', The American Journal of Sociology, Vol. 86, No. 3, pp. 551-583.

25. Shumba, A \& Naong, M 2012, 'Factors Influencing Students' Career Choice and Aspirations in South Africa', Journal of Social Science, pp. 169-178.

26. Tremblay, M, Wils, T \& Proulx, C 1998, 'Determinants of Desired Career Paths among Canadian Engineers', Scientific Series, pp. 1-32.

\section{Fernando, RTW}

Department of Human Resource Management, University of Sri Jayewardenepura

Jayasekara, $\mathbf{P}$

Senior Lecturer, Department of Human Resource Management, University of Sri Jayewardenepura 